\title{
Risk Assessments of Impacts of Climate Changeand Tourism: Lessons for the Mediterranean and Middle East and North African Countries
}

\author{
Mine Cinar ${ }^{1}$, Colton Burns ${ }^{1}$, Nathalie Hilmi ${ }^{2 *}$ and Alain Safa ${ }^{3}$ \\ ${ }^{1}$ Loyola University Chicago, USA \\ ${ }^{2}$ Centre Scientifique de Monaco, Monaco \\ ${ }^{3}$ Skillpartners, France
}

Submission: May 18, 2020; Published: June 04, 2020

*Corresponding author: Nathalie Hilmi, Centre Scientifique de Monaco,8 Quai Antoine 1er, MC 98000, Principality of Monaco, Monaco

\section{Abstract}

Mediterranean (MED) Sea represents 30\% of the world tourism and tourism activity is the main economic driver. On one hand, climate change affects negatively the environment for tourism and, on the other hand, traditional tourism activity contributes to climate change through emissions of greenhouse gases. For a sustainable future, this negative feedback relationship should change. Any environmental structural damage in the region would badly impact the economic and political stability because international tourism receipts have a crucial socio-economic role in the Mediterranean countries.

In order to have a clear idea of risk assessments of the future damage that climate change could cause in the MED region, as well as the means to cope with it, our paper analyzes the risks currently being faced by the Caribbean region which is both an attractive tourist destination and more and more exposed to extreme weather phenomena related to climate change. Our analysis is mainly based on insurance companies' studies. They are at the forefront and were the pioneers in the risk development of models to anticipate future climate damages, including compensation and insurance premiums. This analysis provides a realistic view of what the people of MENA region might experience and what actions can be taken and lessons to be learned.

Added to this microeconomic effect, we introduce a macroeconomic analysis about climatic phenomena in the short and medium terms. The observation of the disasters that Latin America and the Caribbean region have undergone in recent decades shows us the net impact in terms of the economic growth. This gives us an idea of the potential losses in the MENA region and the efforts to be made. This cost-benefit analysis is increasingly integrated into the implementation of climate change policies.

Effective actuarial studies of insurance companies and macroeconomic models incorporating the increasing intensity of extreme weather events are both a good understanding of the reality and a model of effective actions to be undertaken to avoid or to reduce the negative impacts of climate change in MED and Middle East and North Africa (MENA) areas in the future.

Keywords: Mediterranean; Climate change; Damage insurance and risk assessment; Economic development; Environmental impact assessments

\section{Introduction}

\section{Importance of tourism for Mediterranean, Middle East and North African countries}

International tourism is an important economic driver, bringing foreign exchange and helping ease pressure on the balance of payments. Tourism has the potential to lift people out of poverty through the employment and entrepreneurial opportunities it provides, and the recognition of tourism's role in poverty alleviation has made it a substantial component of the international development and trade agenda [1]. The tourism sector also embraces, and has the potential to make a substantial contribution to the achievement of the United Nations' Millennium Development Goals and Sustainable Development Goals [2,3]. This, however, demands that the sector adapts to climate change, and, as important, reduces its contribution to climate change through emissions of greenhouse gasses (GHG) 
and the overall environmental footprint of tourism. Both aspects require substantial changes in the tourism production system. On one hand, with its close connections to the environment and climate itself, tourism is considered to be a highly climatesensitive economic sector similar to agriculture, insurance, energy, and transportation. Indeed, climate change is not a remote future event for tourism, as the varied impacts of a changing climate are even now becoming evident at destinations around the world. On the other hand, tourism contributes to climate change and is affected by catastrophes. Anthropogenic climate change is caused by GHG emitted into the atmosphere, primarily through the burning of fossil fuels. According to UNWTOUNEP-WMO [4], emissions from tourism, including transports, accommodation and activities (excluding the energy used for constructions and facilities for example) account for about $5 \%$ of global $\mathrm{CO}_{2}$ emissions. This is particularly relevant for emissions from aviation. In 2005, tourism's contribution to global warming was estimated to contribute between $5 \%$ and $14 \%$ to the overall warming caused by human emissions of greenhouse. Long haul travel accounts for only $2.7 \%$ of all tourist trips, but contributes $17 \%$ to global tourist emissions.

The Mediterranean (MED), which includes the northern coastal countries of Middle East has long been familiar to tourists because of its perceived good climate. The Mediterranean region (MED) can justifiably claim to have been the focus of the modern tourism industry and yet in recent years it has begun to lose some of its gloss. The tourist industry is by its very nature fragile and susceptible to political, economic and social changes and the probability of climate change adds another element of uncertainty to planning future developments. The MED is no doubt one of the regions in the world most affected by the impacts of climate change on tourism. The countries in the region were historically characterized by the enhancement of resources adapted to the fragility of the natural environment such as water saving, landscape-gardening, etc. This fragile balance has been in some cases disturbed by tourism. Public opinion is more and more concerned by the impact of tourism on the environment. In 1995, 46\% of the Greek population said they were extremely worried about the damage caused by tourism. They were followed by $26 \%$ of the Spanish, $24 \%$ of the Portuguese and $18 \%$ of the Italian populations [5]. In 2009, Polish (19\%), British (18\%), Irish (17\%), Slovene and Romanian (16\%) respondents suggested they would pay attention to ecological concerns in the future [5]. Environmental concerns appeared to be somewhat correlated to age, as well as domestic vs. international travel.

The Intergovernmental Panel on Climate Change [6-8] recorded that the anthropogenic GHG emissions since the pre-industrial era have driven large increases in the atmospheric concentrations of $\mathrm{CO}_{2}, \mathrm{CH}_{4}$, and $\mathrm{N}_{2} \mathrm{O}$. They predict that the pace of climate change is 'very likely' (greater than $90 \%$ probability) to accelerate with continued GHG emissions at or above current rates, with globally averaged surface temperatures estimated to rise by $1.8^{\circ} \mathrm{C}$ to $4.0^{\circ} \mathrm{C}$ by the end of the $21^{\text {st }}$ century [8]. Changes in temperatures and other climatic features will vary globally. It is very likely that hot extremes, heat waves and heavy precipitation events will continue to become more frequent. Tropical cyclones will likely become more intense, with larger peak wind speeds and more heavy precipitation associated with ongoing increases of tropical sea surface temperatures. Decreases in snow cover, already observed in some regions, are projected to continue. The regions affected by these extreme events, including many major tourism destinations, will expand. These predicted changes highlight the need for awareness and preparedness for natural hazards at the local level through systematic capacity building and strategies for disaster risk management $[9,10]$. Evidence from past catastrophes as well actuarial approaches to the environment are discussed in the sections below.

Being one of the most significant sustainability risks, global warming has created problems that extend beyond the environment. Besides tragic human losses to extreme events, there are also property risks due to losses like floods, hurricanes, and typhoons, liability risks from different lawsuits, and life/health risks that allow diseases to spread easier, creating heat stress globally, and develop environmental injustice towards poorer countries. Environmental liability risks result in large damages and high costs when the liability event takes place, examples are seen in cases like the Exxon Valdez oil spill. Ecosystems are harmed with continual avoidance of sustainability risks by companies. Through the painful transition that our current environment is faced with, sustainable environmental risk management control systems must be instilled into the business world. From an actuarial standpoint, companies that incorporate a sustainability strategy have potential to increase sales, profits and stock valuations while decreasing costs and boosting their reputation. Anderson already in 2005 discusses sustainability risk management and focuses on the obligation of corporations to be conscientious of the environmental and social impact that is created through the processes of their products.

Tourism income is essential for most countries in the MED and MENA. . Yet in 2013, arrivals in the Middle East (-9\%) and North Africa (-15\%) have been very seriously affected by the "Arab Spring". Results varied across individual destinations [9]. The United Arab Emirate of Dubai's tourism arrivals grew at a robust pace of $11 \%$, while Palestine $(+11 \%)$ and Oman $(+8 \%)$ also reported healthy growth. Other destinations faced declines. The region's top destination Saudi Arabia reported 7\% less tourist arrivals than in 2012, Egypt posted double-digit growth in the first half of the year, but saw a significant drop in arrivals in the second half due 
to renewed political tension in the country, leading to an overall decrease of $18 \%$. Lebanon $(-7 \%)$ and Jordan $(-5 \%)$ continued to suffer from the conflict in neighboring Syria [9]. Before 2011, the Middle East was the fastest growing region in $2010(+14 \%)$, followed a significant drop in $2009(-4 \%)$ in link with the 2008 financial crisis, and more recently with a decline in 2016 (-4\%). According to UNTWO [9], international tourism receipts in the Middle East are estimated to accumulate to US $\$ 57.6$ billion, but with a drop of $-56.4 \%$ for Egypt, and a slight decrease of $-0.005 \%$ for Lebanon and an increase of $+7.62 \%$ for Saudi Arabia. 2016 International tourist arrivals in Africa increased by an estimated
8\% in 2016 according to the comparatively limited data available to date, representing a strong rebound after a weaker performance in 2014 and 2015 in the wake of various health, geopolitical, and economic challenges. Asmall decline amid challenges International arrivals in the Middle East are estimated to have decreased by $4 \%$ in 2016, with mixed results across the region where solid growth in some destinations was not sufficient to offset decreases in others [9]. Table 1 below, compiled from UNWTO 2017, lists the international tourism arrivals and receipts in MENA countries between 2010-2016.

Table 1: Tourism Arrivals and Receipts in Millions USD for MENA.

\begin{tabular}{|c|c|c|c|c|c|c|c|c|}
\hline \multirow{3}{*}{ Destination } & \multicolumn{4}{|c|}{ Arrivals } & \multicolumn{4}{|c|}{ International Tourism Receipts } \\
\hline & \multicolumn{4}{|c|}{ Number of Tourists } & \multicolumn{4}{|c|}{ (Millions of USD) } \\
\hline & 2010 & 2014 & 2015 & 2016 & 2010 & 2014 & 2015 & 2016 \\
\hline Middle East & 55,442 & 55,267 & 55,622 & 53,567 & 52,150 & 53,556 & 58,168 & $\mathbf{5 7 , 5 9 5}$ \\
\hline Bahrain & 995 & 838 & 1,200 & & 1,263 & 1,197 & $* *$ & $* *$ \\
\hline Egypt & 14,051 & 9,628 & 9,139 & 5,258 & 12,528 & 7,208 & 6,065 & 2,645 \\
\hline Iraq & 1,518 & $* *$ & $* *$ & $* *$ & 1,660 & 2,489 & 4,060 & 2,423 \\
\hline Jordan & 4,207 & 3,990 & 3,761 & 3,858 & 3,585 & 4,375 & 4,065 & 4,044 \\
\hline Kuwait & 207 & 198 & 182 & & 290 & 369 & 499 & 599 \\
\hline Lebanon & 2,168 & 1,355 & 1,518 & 1,688 & 7,995 & 6,523 & 6,857 & 6,824 \\
\hline Libya & $* *$ & $* *$ & $* *$ & $* *$ & 60 & $* *$ & $* *$ & $* *$ \\
\hline Oman & 1,441 & 1,611 & 1,897 & & 780 & 1,276 & 1,540 & $* *$ \\
\hline Palestine & 522 & 556 & 432 & 400 & 667 & 603 & 452 & $* *$ \\
\hline Qatar & 1,700 & 2,826 & 2,930 & 2,906 & 584 & 4,591 & 5,035 & 5,411 \\
\hline Saudi Arabia & 10,850 & 18,260 & 17,994 & 18,049 & 6,712 & 8,238 & 10,130 & 11,096 \\
\hline Syria & 8,546 & $* *$ & $* *$ & $* *$ & 6,190 & $* *$ & $* *$ & $* *$ \\
\hline UAE & 7,432 & 13,200 & 14,200 & 14,910 & 8,577 & 15,221 & 17,481 & 19,496 \\
\hline Yemen & 1,025 & 1,018 & $* *$ & $* *$ & 1,161 & 1,026 & 100 & $* *$ \\
\hline
\end{tabular}

According to UNWTO (2017), the most attractive countries by the amount of international tourist receipts in descending order and without the GCC countries are Egypt, Lebanon, Morocco, Jordan,

and Tunisia. Total receipts of selected countries in the MED region are given below in Table 2 .

Table 2: Tourism Arrivals and Receipts in Millions USD for Some Countries around the MED.

\begin{tabular}{|c|c|c|c|c|c|c|}
\hline \multirow{2}{*}{} & \multicolumn{2}{|c|}{ International Tourist Arrivals } & \multicolumn{3}{c|}{ International Tourism Receipts } \\
\cline { 2 - 6 } & \multicolumn{2}{|c|}{ In Thousands } & Change \% & \multicolumn{2}{c|}{ US\$ Million } & Change \% \\
\cline { 2 - 7 } & $\mathbf{2 0 1 6}$ & $\mathbf{2 0 1 7}$ & & $\mathbf{2 0 1 6}$ & $\mathbf{2 0 1 7}$ & \\
\hline Spain & 115,561 & 121,677 & $5 \%$ & $\$ 60,605$ & $\$ 68,437$ & $13 \%$ \\
\hline France & 203,042 & 207,369 & $2 \%$ & $\$ 62,965$ & $\$ 69,894$ & $11 \%$ \\
\hline Monaco & 336 & 355 & $6 \%$ & & & $10 \%$ \\
\hline Italy & 84,925 & 89,931 & $6 \%$ & $\$ 40,373$ & $\$ 44,548$ & 104 \\
\hline
\end{tabular}




\section{International Journal of Environmental Sciences \& Natural Resources}

\begin{tabular}{|c|c|c|c|c|c|c|}
\hline Slovenia & 3,032 & 3,586 & $18 \%$ & $\$ 2,627$ & $\$ 2,952$ & $12 \%$ \\
\hline Croatia & 57,587 & 59,238 & $3 \%$ & $\$ 9,820$ & $\$ 11,128$ & $13 \%$ \\
\hline Bosnia and Herzegovina & 778 & 923 & $19 \%$ & $\$ 772$ & $\$ 894$ & $16 \%$ \\
\hline Montenegro & 1,662 & 1,877 & $13 \%$ & $\$ 978$ & $\$ 1,109$ & $13 \%$ \\
\hline Albania & 4,736 & 5,118 & $8 \%$ & $\$ 1,829$ & $\$ 2,049$ & $12 \%$ \\
\hline Greece & 28,071 & 30,161 & $7 \%$ & $\$ 16,533$ & $\$ 17,929$ & $8 \%$ \\
\hline Turkey & 30,907 & 37,970 & $23 \%$ & $\$ 26,788$ & $\$ 31,870$ & $19 \%$ \\
\hline Syria & & & & & \\
\hline Israel & 3,070 & 3,863 & $26 \%$ & $\$ 6,587$ & $\$ 7,572$ & $15 \%$ \\
\hline Malta & 2,592 & 2,944 & $14 \%$ & $\$ 1,451$ & $\$ 1,746$ & $20 \%$ \\
\hline Cyprus & 3,286 & 3,750 & $14 \%$ & $\$ 2,757$ & $\$ 3,128$ & $13 \%$ \\
\hline
\end{tabular}

We conclude that the international tourism receipts have a crucial socio-economic impact in these countries. In Lebanon, international tourism receipts represent more than $30 \%$ of total exports and $15 \%$ of total imports.

Catastrophe damage has been studied and quantified by and for the Caribbean islands. Even though, MED and MENA are not subject to hurricanes, gradual environmental damage (and accidental damage) with high levels of urbanization and high reliance on tourism make them very vulnerable. Study of the Caribbean hurricane disasters and mitigation can shed light to other regions of the world which are subject to floods, draughts and earthquakes. Sections below describe the insurance industry and the mitigation efforts of the Caribbean region who have decades of history in disasters.

\section{Risk, Actuarial Statistics, Insurance and the Caribbean}

With the Caribbean islands so dependent on tourism for economic growth, the effects of environmental disasters hold immense value. From construction to pollution, the Caribbean is facing serious dangers with their changing environment. Among the impacts of climate change are a more regular occurrence of intense rains, a rise in sea level, and greater intensity of hurricanes $[11,12]$. With such high levels of pollution, oceans have managed to absorb one-third to one-half of carbon dioxide emissions. Such high concentrations of carbon dioxide have created ocean acidification, which is hindering the ability of marine organisms to create calcium carbonate-based shells and skeletons. Coral reefs are harmed by increased carbon dioxide levels in the water as well as temperature increases. Coral reef health holds significant value because they provided a benefit of \$3-4.5 billion annually from fisheries, tourism, and shoreline protection as of 2004 [13]. This idea seems especially important since only 25 percent of coral reefs in the Caribbean are considered to be in good health [14]. With this damage occurring to the Caribbean environment, a reduction in tourism may pose the largest threats to tourism which include infrastructure risks (roads, hotels, beaches) due to rising sea levels and aggressive waves as well as an expectation from tourists to be in an immaculate environment for resources as simple as clean water.

The purchase of insurance is a transfer of risk from the policyholder to the insurer. Since the insurer's risk for a pool of policyholders is less than the risk of the sum of the individual policyholder's risks, this exchange of risk proves beneficial for both parties. As the standard deviation - or the variation - of an expected outcome increases, the potential for risk is also increased. Two random variables are important when calculating potential loss for a policyholder: the frequency of loss and the severity of the loss. The expected value and standard deviation of the loss have much importance for actuaries when determining financial plans. In order for a risk to be insurable, the loss must be independent of other policyholder's losses in that pool. The loss needs to be out of the policyholder's control and significant enough such that it is worth insuring.

The insurance firm's main goal is to develop the loss distribution from the frequency and severity distributions. This data allows them to find expected values and variations of benefits and expenses. Analysis of these numbers permits the actuary to determine a net premium for the policyholder that offers the insurance company with the greatest opportunity for return while keeping fair prices for both parties. Insurance is defined by an agreement between a policyholder and an insurer where the policyholder pays a premium with the tradeoff being that the insurer will make a claim payment in the event of a loss occurring to the policyholder. Since the purchase of insurance is essentially a transfer of risk from the policyholder to the insurer, and since the insurer's risk for a pool of policyholders is less than the risk of the sum of the individual policyholder's risks, this exchange of risk proves beneficial for both parties. As the standard deviation - or the variation - of an expected outcome increases, the potential for risk is also increased.

It has now become apparent that the environment is following a "new normal" and must be approached differently when attempting to assess or predict future outcomes [7]. Since oceans transport latent heat energy and water to the atmosphere, oceans are capable of developing weather patterns and supplying the 
energy required for an extreme event to occur. With these changes in the environment, predicting catastrophic events and their damages becomes much more challenging. A main driver in the changing loss potential of these events is the rising sea levels. Byproducts of the rising sea levels are increased flood risks and higher potential for impacts of storms [7]. Another main contributor is the intensified hydrological cycle: exchanging energy between the oceans and the atmosphere has seen an exponential increase in evaporation due to the temperature increase in the water [60]. With more water in the atmosphere, there is more humidity, precipitation, and energy for convection. These increases combine to provide increased potential intensity during precipitation events $[15,16]$. Other impacts of oceanic temperature increases are more intense tropical cyclones $[11,17,18]$, extra-tropical winter storms, and uncertain future for marine ecosystems. Some biotic members of the marine ecosystems depend on specific water temperatures and acidity levels; recent ocean acidification has contributed to loss of biotic underwater life.

There are analytical problems in predicting these risks because the "new normal" lacks a formal, usable definition and probabilities cannot be assigned with high confidence. Estimating risks and quantifying the changes pose the greatest problems for the insurance industry, especially because there has been an upward trend in insured losses from extreme weather events on both local and large-scale levels. Analysis of past events shows that the threat of natural catastrophes is ambiguous. An internal approach by the insurance industry to resolve the estimation problem attempts to finds a better way to predict these events, specifically, by using an unbiased set of scenarios to price ambiguous insurance contracts (see different forecasting models in Hurricanesscience [19]). An external approach that could make ambiguous risks insurable would be by promoting risk mitigation [20], or in other words, for the insurance industry to raise awareness of risk and climate change [21]. By involving the public and encouraging activity in the issue, the insurance industry can use new innovations and ideas to avoid market failures and increase societal resilience in MENA and MED countries. These regions see gradual degradation of the environment, but can nevertheless learn from the experiences of the Caribbean islands.

It is not easy to simulate catastrophe damage in places which depend heavily on tourism. One can start to get an estimate of historic insurance payments to places which are heavily urbanized. Below is Table 3 which lists the estimated and actual insurance payments of hurricane Katrina per insurance company.

Table 3: Estimated and actual insurance payments on Katrina by insurance companies

\begin{tabular}{|c|c|c|c|c|}
\hline Natural Disaster & Total Insurance Payout & $\begin{array}{c}\text { Overall } \\
\text { Damages }\end{array}$ & Insurer & $\begin{array}{c}\text { Estimates and Payouts by Some Insur- } \\
\text { ance Companies }\end{array}$ \\
\hline \multirow{6}{*}{ Hurricane Katrina } & \multirow{6}{*}{ \$41.1 Billion (Actual) } & \multirow{6}{*}{ \$108 Billion } & AIG, Estimate 9/20/05 & $\$ 1.1$ Billion \\
\hline & & & $\begin{array}{l}\text { Lloyd's of London, Estimate } \\
\qquad 9 / 20 / 05\end{array}$ & $\$ 2.55$ billion \\
\hline & & & $\begin{array}{l}\text { Swiss Reinsurance Company, } \\
\text { Estimate } 9 / 20 / 05\end{array}$ & $\$ 1.2$ Billion \\
\hline & & & Berkshire, Estimate 9/21/05 & $\$ 2$ Billion \\
\hline & & & Allstate, Actual 10/20/05 & $\$ 3.68$ Billion \\
\hline & & & State Farm, Actual 8/22/10 & $\$ 3.8$ Billion \\
\hline
\end{tabular}

Sources: AIG, Lloyd's and Swiss Reinsurance Company estimates from NBC (9/22/2005). Berkshire Estimate from Taub, 2005. Actual payments by Allstate are from Sachdev (2005) and by State Farm are from Denham (2010). Notes: Despite AIG's estimated payout of $\$ 1.1$ billion in September of 2005, their 2006 annual report recorded losses at $\$ 62$ million from Hurricane Katrina (American International Group Inc., 2006). With estimated losses of $\$ 2.55$ billion in September of 2005 , Lloyd's of London included a combined total loss of $£ 3.3$ billion (approximately $\$ 5.1$ billion) from hurricanes Katrina, Rita, and Wilma in their 2005 annual report (Lloyd's of London, 2005). The Swiss Reinsurance Company estimated their payout from Katrina to be $\$ 1.2$ billion in their 2005 annual report (Swiss Reinsurance Company, 2005). Berkshire Hathaway estimated their Katrina losses to be $\$ 2$ billion in September of 2005, and their 2006 annual report showed a combined loss of $\$ 2.5$ billion from hurricanes Katrina, Rita, and Wilma (Berkshire Hathaway Inc., 2006). The actual losses for Allstate, provided in October of 2005, were \$3.68 billion (Sachdev, 2005). A thorough summary of the Katrina losses for State Farm were given 5 years after the event, in August of 2010, where State Farm is said to have lost $\$ 3.8$ billion (Denham, 2010). Hurricane Sandy had smaller looses than Katrina, with overall damages of $\$ 50$ billion and an actual insurance payout of $\$ 18.75$ [22-29].

How to Limit Risks: Mitigation, Vulnerability and

\section{Insurance in the Caribbean}

The Caribbean Disaster Mitigation Project [30] aims to counter the detrimental effects of natural disasters by publicly discussing the improvements that are needed when assessing risk. The main objective of the project is to develop mitigation strategies to lessen the damage that natural disasters cause to human lives and their properties. Since the insurance industry is directly involved in catastrophe events, and since the price of property insurance in the Caribbean has been significantly high, the CDMP focused much of their attention on incorporating insurance firms into their programs. With natural disasters occurring at a dangerously high rate, the reinsurance market began charging higher premiums and the primary insurers had no choice but to raise prices for their 
policyholders. To encourage homeowners to purchase insurance, the first programs created by the CDMP targeted the problem of high premium rates.

Kleindorfer \& Kunreuther [31] in 1999 discussed different strategies that help to encourage mitigation, such as strict enforcement of building codes, loans being provided by banks for various mitigation strategies, and insurers lowering deductibles for policyholders that invest in retrofitting their homes. Insurers would benefit from the reduction in premiums if, firstly, the retrofitted homes showed significant resistance to natural disasters, and also if reinsurance premiums were reduced enough such that the insurer's reduction in premium income is at least offset by the savings received from the reduced reinsurance premium. The cheaper premium rates for retrofitted homes did not yield much success when applied in Barbados; however, the program saw much better results when it was redesigned and launched in Antigua and Barbuda.

Despite the new, innovative techniques for cheaper insurance by promoting mitigation, there are still a large portion of Caribbean homes that stand uninsured, and it is estimated that about $30 \%$ of insurable properties of Caribbean Regional Integration community CARICOM countries are uninsured. The high deductibles and premium rates cause homeowners to shy away from purchasing insurance - especially in low-income segments of the Caribbean. To assist this issue, national awareness campaigns and loan funds were created to educate the public of the importance of restructuring homes to be more stable against natural disasters.

The insurance industry can be linked into the proper construction of their infrastructures process by using initiatives to control the quality of projects, seeing that they are strong and reliable. Additionally, lenders should get involved by requiring infrastructures to be insured as a condition before any loans are given out, especially before any construction begins.

\section{Macroeconomic Effects on a Country after a Natural Disaster and Insurance}

Importance of insurance against natural disasters are important, not only for their macroeconomic effects but also for preserving the wealth and assets of households. Various case studies have been executed to answer the polarizing debate on whether or not there are negative macroeconomic effects on a country following a natural disaster. On the side that argues for the existence of these negative impacts, various studies by ECLAC [32-37] show severe negative economic impacts in the shortterm. These impacts involve problems to agriculture, increases in inequality and poverty, growing debt, deficits, inflation, and slowed growth in GDP, among others. It is accepted that these economic concerns are diminished in the long-run. There are also studies performed for the opposite side of the argument, namely by Albala-Bertrand [38], that support the idea that natural disasters do not stunt GDP growth rates and even have potential to improve them. His statistical analysis in accordance with ECLAC research shows that he could not reject the hypothesis that labor and capital stock have no impact on economic growth in the shortrun $[39,40]$. To properly analyze natural disasters, it is important to describe these events as a function of hazards (types, intensity, and recurrence), exposure (elements exposed to hazards), and vulnerability [41].

One strategy to analyzing the macroeconomic effects of natural disasters is to compare the observed GDP before and after the disaster with a projected GDP if the disaster had not occurred. This projected GDP is calculated using autoregressive integrated moving average models, which uses maximum likelihood functions and parameter estimates to create a model. Statistical analysis shows that the median GDP can be expected to fall $4 \%$ points in the $5^{\text {th }}$ year after the disaster. Hypothesis testing proves that there is significant evidence to show that the median reduction in GDP is less than zero.

We can show below in Figure 1 as to what happens to GDP by the extreme natural disaster in a country. The damage that disasters cause to assets and capital is seen as a direct damage. There are also indirect damages that are described as the disturbance of the flow of goods and services, leading to lost potential production. It has been estimated that the annual average costs of natural disasters in Latin America and the Caribbean from 1970-1999 ranges from $\$ 700$ million to $\$ 3.3$ billion. Empirical evidence shows that GDP growth decreases by $2 \%$ on average in the year of a disaster, but then picks up and increases an average of $3 \%$ during the next two years [42].

There is such a wide variation in macroeconomic effects across the Latin American and Caribbean region because the proportion of direct and indirect damages with respect to the economy, the type of disaster, and the overall vulnerability changes on a case-tocase basis. Table 4 reports historical losses to GDP as a percentage with recorded events.

Natural disasters have asymmetric damages, where lower income people may not be able to recover between disasters when they occur frequently, and this creates an inequality in the distribution of income among areas, social classes, or genders. Approximately 1,309 natural disasters occurring in the Latin American and Caribbean region over the last 100 years, with an upward sloping trend line in the number of natural disasters throughout that time period, although, this may be due to a lack of reliable data in earlier years. Despite having the second most number of disasters, Latin America and the Caribbean have low fatalities in comparison with other continents, especially among developing regions. Regardless of the regularity of disaster occurrence in Latin America and the Caribbean, it is important to note that they received barely any assistance from insurance, with only $3.9 \%$ of their total losses being covered by insurance from 1985-1999 [42]. 


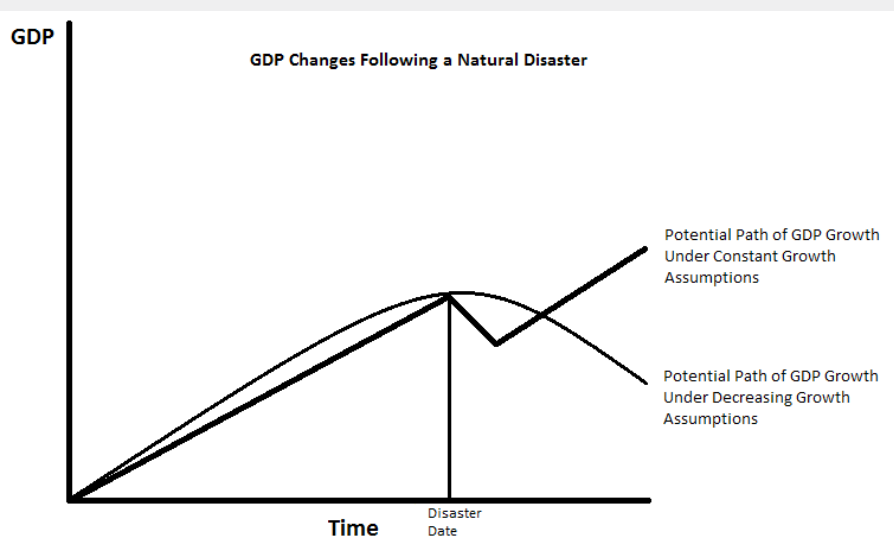

Figure 1: Potential GDP after Disasters.

Table 4: Selected Disaster Cases and GDP Losses.

\begin{tabular}{|c|c|c|c|}
\hline Country & Year & Type of Hazard & Loss as Share of GDP (\%) \\
\hline Argentina & 1985 & Flood & $1.48 \%$ \\
\hline Bahamas & 1992 & Hurricane & $8.75 \%$ \\
\hline Barbados & 1987 & Hurricane & $6.86 \%$ \\
\hline Bolivia & 1982 & Flood & $19.80 \%$ \\
\hline Bolivia & 1986 & Flood & $1.26 \%$ \\
\hline Bolivia & 1988 & Drought & $1.09 \%$ \\
\hline Bolivia & 1992 & Flood & $1.63 \%$ \\
\hline Brazil & 1984 & Flood & $1.00 \%$ \\
\hline Chile & 1985 & Earthquake & $9.10 \%$ \\
\hline Colombia & 1983 & Earthquake & $1.06 \%$ \\
\hline Colombia & 1985 & Volcano & $2.87 \%$ \\
\hline Costa Rica & 1988 & Hurricane & $1.50 \%$ \\
\hline Costa Rica & 1991 & Earthquake & $8.87 \%$ \\
\hline Costa Rica & 1996 & Flood & $2.73 \%$ \\
\hline Ecuador & 1982 & Flood & $1.68 \%$ \\
\hline Ecuador & 1987 & Earthquake & $6.65 \%$ \\
\hline Ecuador & 1993 & Landslide & $3.50 \%$ \\
\hline Guatemala & 1982 & Flood & $1.20 \%$ \\
\hline Haiti & 1988 & Hurricane & $4.09 \%$ \\
\hline Honduras & 1982 & Tropical storm & $3.44 \%$ \\
\hline Honduras & 1990 & Flood & $1.57 \%$ \\
\hline Honduras & 1993 & Hurricane/Flood & $3.39 \%$ \\
\hline Jamaica & 1980 & Hurricane & $2.39 \%$ \\
\hline Jamaica & 1986 & Flood & $3.00 \%$ \\
\hline Jamaica & 1988 & Hurricane & $28.21 \%$ \\
\hline Jamaica & 1991 & Flood & $6.62 \%$ \\
\hline Mexico & 1985 & Earthquake & $2.18 \%$ \\
\hline Nicaragua & 1982 & Tropical storm & $18.74 \%$ \\
\hline
\end{tabular}




\section{International Journal of Environmental Sciences \& Natural Resources}

\begin{tabular}{|c|c|c|c|}
\hline Nicaragua & 1988 & Hurricane & $32.57 \%$ \\
\hline Nicaragua & 1992 & Earthquake & $8.36 \%$ \\
\hline Nicaragua & 1994 & Drought & $1.23 \%$ \\
\hline Panama & 1988 & Hurricane & $1.36 \%$ \\
\hline Paraguay & 1983 & Flood & $5.96 \%$ \\
\hline Peru & 1983 & Flood/drought & $85.42 \%$ \\
\hline St. Kitts \& Nevis & 1995 & Hurricane & \\
\hline
\end{tabular}

Source: Charvériat [42]

One way to view risk from natural disasters is to see it as a function of natural hazards and vulnerability. Unlike the former which cannot be predicted as to strength, the latter can be controlled in some degree by studying risk management and applying it to a region [42]. By studying empirical evidence from past disasters, it can be seen that floods occur the most and yield the greatest monetary loss, earthquakes produce the most fatalities, and drought affects the population the most in the Latin American and Caribbean region. With more scientists agreeing on climate change and its effects, it is predicted that there will be increased rainfall with greater intensity, leading to flooding on the west coast of Central and South America as well as droughts in Latin America and the Caribbean. Rising sea levels - a byproduct of climate change - creates concerns for the Caribbean because their economy relies heavily on tourism, and these increasing sea levels will cause the Caribbean to lose its appeal to tourists, mainly because of flooding and erosion [43].

Vulnerability plays a role in the magnitude of damage that a disaster can cause to an area. The vulnerability of a region typically depends on three variables: the amount of people and assets in a high probability disaster zone, the sensitivity of these people and assets to the impact of disasters, and environmental degradation. Since about $60 \%$ of the Latin American and Caribbean population lives on the coasts - the most vulnerable areas to weather-related hazards - they have a high vulnerability [42]. Because there is such a reliance on coastal economic activities (tourism, fishery, trade) for GDP growth, this region may become more vulnerable if global warming persists [44]. The poor structure of housing in Latin America and the Caribbean also contribute to a higher vulnerability.

To better prepare for natural disasters, there must be risk management decisions made both before and after the event. With low frequency risks, like natural disasters, there is a higher chance for irrational decision-making because the lack of data for analysis causes the risks to be more complex to understand and predict. Vulnerability can be reduced at the household level by limiting the number of assets that are exposed to disasters as well as investing in hazard-resistant technology. Utilizing silos and diversifying income are measures that can be taken at the community level. According to Donahue [45], there are three stages when strategizing loss management: reversible mechanisms and removal of self-insurance assets, discarding of productive assets, and destitution Donahue [45] as cited by Joint United Nations Program on HIV/AIDS (1999, p. 18)). Ritchie $[46,47]$ states that even though crisis cannot be predicted, it can be managed by public and private officials by using pre-planned management tools by studying literature of previous tourism disaster research and hazard tools and approaches from current diverse fields such as education, sociology, and communication.

Another significant part of risk management is risk identification so that warnings of potential disasters can be spotted and communities can be more prepared for the event. Being prepared for a natural disaster is the best means to limiting its destruction. Financial preparedness involves insurance, national reserve funds, and contingency financing to allow for quick transferring of funds to support rehabilitation. Use of social media as well as radios and television can now be used for early warning signs to warn public of immediate disasters.

Overall, the Latin American and Caribbean region needs improvements on risk identification and prevention techniques. Vulnerability in the poorly constructed infrastructures adds to the indirect costs, since reconstruction require more funds. Without a profitable solution to urbanization and high insurance rates, the region has a high dependence on other nations to assist them after a natural disaster. Investing in risk reduction and promoting mitigation policies to be more prepared for disasters is the best solution for Latin America and the Caribbean to reduce their vulnerability. Instead of focusing on post-disaster strategies, it would prove to be much more beneficial to look at preparation techniques, risk identification, and other incentives for risk reduction.

Game theoretic models can be used to structure and analyze problems in the environment that involve strategic choices $[48,49]$. By using a revenue loss matrix, one can examine the threats that coral reefs and the stakeholders face. In this case, the stakeholders are the people/groups that will suffer from the loss of coral reefs. Among the uses of coral reefs is shoreline protection, a habitat for 
marine life, biodiversity sustainability, and a strong attraction for tourists. Research shows that the greatest threats to coral reefs are overexploitation, coastal development, land-based pollution, and marine pollution.

Once the revenue loss matrix is set up for coral reef threats and stakeholder threats, expected losses can be calculated for specific stakeholders (global, national revenue, tourism industry, and food industries). Expected losses can also be assigned to carbon dioxide, unsustainable tourists, overfishing, and algae. These expected losses should be analyzed to implement policies that minimize the maximum losses. The maximum loss will depend on the probabilities for threats subject to a given region and the estimates for potential damage when the coral reefs lose their ability to adapt to their changing environment. Increasing the resilience of coral reefs can be achieved with communitybased natural resource management to protect.

A way to reduce the potential damage that a natural disaster can cause is by studying and assessing the risk that is associated with these disasters. Assessing risk is typically done through actuarial work and acts as a preparation strategy before a catastrophe occurs. These assessments allow the opportunity to transfer risk with insurance and reinsurance, as well as control its damage with mitigation and other techniques. A factor that could reduce risk and damage caused by natural disasters is the integration of stronger infrastructures on housing. Insurance companies can offer cheaper premiums to homeowners that retrofit their homes to better resist the trauma of a disaster. This incentive-based policy could reduce the total losses and provide drastic improvements in the rebuilding process following a natural disaster.

An actuary can provide the statistical analysis of natural disaster risks; however, it is the responsibility of the insurance and reinsurance industries to keep their prices low enough to encourage the purchase of their services. The insurance companies are also asking their actuaries to consider the probability of a ruin: the likeliness of the insurer to provide more money in claims than it gains in premiums. The incentive-based insurance helps to minimize the amount that the insurer will have to pay in claims after a disaster, thus allowing for a cheaper premium to be sent to the homeowner.

An idea that is similar to the incentive-based insurance policies as stated above is to have universities monitor the regional environment. This is a similar concept because the university can incorporate its students to play an active role in the monitoring process, creating an incentive for students to get involved directly in the project as well as indirectly through word of mouth. The findings can be released to the public which will raise awareness of an issue that may not be universally understood. With consistent regional data that are collected from the oceans and land, more conclusions will be drawn and the issue can be better understood by researchers. This will allow a better opportunity for resolutions to be developed.

\section{Conclusion}

Munich Reinsurance [50] found that insured losses from natural disasters in the 1990s are 15 times greater than in the 1960s. Similarly, the economic losses are eight times greater than in the 60s. An easy explanation for drastic increase in losses is the fact that the number of natural disasters that have occurred in this decade are four times greater than that in the 1960s, this number debatably stemmed from the effects of climate change. Other reasons include population growth in high risk areas (for example, along the coasts), insured values rapidly rising, expanding coverage in the insurance industry, and lack of government organization to properly enforce appropriate building codes. Nutter [51] writes that the insurance industry has direct ties to climate and weather because they can only survive as a business if they can estimate future damages appropriately. The insurance industry is finding out that they cannot provide insurance coverage for natural disasters solely based on historical data adjusted for inflation. The unpredictability of the current climate is forcing insurance firms to reanalyze their coverage policies to avoid dying as a business.

Nutter [51] states that the insurance industry reacted in three ways to the new uncertainty associated with natural disasters: they raised premiums and, in some cases, even withdrew their coverage; they involved the state and federal government to have a "safety net" for the insurance industry; and they invested in studying the science of natural disasters to better understand their effects so they can discover ways to mitigate these effects. Using computer models, insurance companies are incorporating actuarial science research into the current knowledge about extreme events to find appropriate pricing strategies for the property and casualty insurance industry. The insurance industry is also expanding their options to policyholders so that they can choose a policy with a fair deductible and premium that best suits their insurance needs. Another effort of the insurance industry is to evaluate building codes and investigate their enforcement so that losses can be minimized in the event of a natural disaster. On the side, there is research being done on global warming so that the insurance industry can better understand the problem that they are trying to price. MED and MENA have much to learn about disaster mitigation and developing private and public insurance to limit damages. Human and asset losses can be reduced, especially in MED and MENA by examining the Caribbean experience for the purpose of applying the best policies as soon as possible (Appendix) [52-59]. 


\section{Appendix}

\section{Using the Probability of a Ruin in Estimating Maximum Environmental Damage}

With use of computers, new methods were developed to approximate the probability of ruin. One method, mainly credited to Goovaerts \& De Vylder [52], discovered a connection between the probability of a ruin and a geometric random variable that is the maximum aggregate loss. The probability of a ruin can be calculated from the probability of survival where the probability of survival is described by:

$$
1-\psi(u)=P(L \leq u)=\sum_{n=0}^{\infty}(1-q) q^{n} H^{*_{n}}(u)
$$

where $1-\psi(u)=P(L \leq u)$ is the probability of survival, $L=L_{1}+L_{2}+\ldots \ldots+L_{n}$ being the maximal aggregate loss and $u$ being the initial surplus, $q=\frac{1}{1+\theta}=\psi(0)$ with $\theta$ as the relative security loading, and $H^{* n}(u)$ follows from the distribution function for all the $L_{i}$ which is equal to $H(x)=\frac{1}{p_{1}} \int_{0}^{x} 1-P(y) d y$ where $p_{1}$ is the mean claim size and $P(y)$ is the individual claim amounts. In the case where there are negative claim amounts, the first method fails and another method must be considered. This second process generalizes the first and considers the distribution for claim amount to be a combination of exponentials or a translated combination of exponentials. The density for the latter can be read as:

$$
p(x)=\sum_{l=1}^{n} A_{l} \beta_{l} e^{-\beta_{l}(x+\tau)}
$$

Where $A_{l}$ is the claim amount, $\beta_{l}$ is a positive parameter, and is the translation amount. The density for the former is simply a special case where $\tau=0$. The probability of a ruin with this method can be calculated as illustrated below:

$$
\psi(u)=\sum_{k=1}^{n} C_{k} e^{-r_{k} u}
$$

Where $r_{1}, r_{2} \ldots ., r_{n}$ are the $n$ roots of the equation $\lambda+c r=\lambda \sum_{l=1}^{n} A_{l} \frac{\beta_{l}}{\left(\beta_{l}-r\right)} e^{-r t}-$ with $c$ being the rate at which premiums are received - and $C_{1}, C_{2}, \ldots ., C_{n}$ are the solutions to the following system of linear equations: $\sum_{k=1}^{n} \frac{\beta_{k}}{\beta_{k}-r_{k}} C_{k}=1$.

Determining the nontrivial roots in the second method may present computational difficulties, thus there is a third method to calculate the probability of a ruin. This process uses computer simulations and relationships between the probability of a ruin and the stationary distribution of a certain associated procedure.

The probability of a ruin can be illustrated in a scenario where an individual begins playing a game with a set amount of money $-i$ - and gambles to either win a dollar or lose a dollar. In this example, the probability of winning a dollar is $p$ and the probability of losing a dollar is $q=1-p$. The goal of the gambler is to reach a total fortune $-N$ - before losing all of their money. In this case, going broke is thought to be the ultimate ruin. The game continues until the participant either reaches their total fortune or faces ultimate ruin. The probability of reaching the total fortune is found to be:

$$
P_{i}=\left\{\begin{array}{l}
\frac{1-\left(\frac{q}{p}\right)^{i}}{1-\left(\frac{q}{p}\right)^{N}}, \quad p \neq q \\
\frac{i}{N}, \quad p=q=0.5
\end{array}\right.
$$

This procedure can be extended to look at risk by analyzing the probability of a ruin for an insurance company. When a random walk occurs, a similar method is used to calculate the probability of reaching $N=a+b$ when $i=b$ :

\begin{tabular}{|c|c|c|c|c|c|}
\hline Initial Endowment in dollars = i = & 10 & 10 & 10 & 10 & 10 \\
\hline Fortune Goal in Dollars = N = & 30 & 30 & 30 & 30 & 30 \\
\hline Probability of a Success $=p=$ & 0.6 & 0.1 & 0.5 & 0.7 & 0.05 \\
\hline Probability of Failure $=\mathrm{q}=$ & 0.4 & 0.9 & 0.5 & 0.3 & 0.95 \\
\hline Probability of Reaching Fortune $=\mathrm{P}=$ & 0.982664 & 8.23E-20 & 0 & 0.999791 & $2.66 \mathrm{E}-26$ \\
\hline
\end{tabular}

$$
P_{i}=\left\{\begin{array}{l}
\frac{1-\left(\frac{q}{p}\right)^{b}}{1-\left(\frac{q}{p}\right)^{a+b}}, \quad p \neq q \\
\frac{b}{a+b}, \quad p=q=0.5
\end{array}\right.
$$

As an example, if we have an initial endowment and we have a target goal in mind, we can construct tables that give us the probability of reaching that goal if we know the probability of success. Dufresne \& Gerber [53] have such a table they construct with the following numbers: 
Using this sort of an analysis gives us the probability of reaching our goal, which is on the last line of the above table. This analysis can easily be applied to MED and MENA for tourism related damages.

\begin{tabular}{|c|c|c|c|c|c|}
\hline Initial Tourism Income in Dollars = i = & 10 & 10 & 10 & 10 & 10 \\
\hline Increased Goal of Tourism Revenues $=\mathrm{N}=$ & 30 & 30 & 30 & 30 & 30 \\
\hline Probability of a Sustainable Environment $=\mathrm{p}=$ & 0.6 & 0.1 & 0.5 & 0.7 & 0.05 \\
\hline Probability of Environmental Damage $=\mathrm{q}=$ & 0.4 & 0.9 & 0.5 & 0.3 & 0.95 \\
\hline Probability of Reaching Sustainable Environment $=\mathrm{P}$ & 0.982664 & $8.23 \mathrm{E}-20$ & 0 & 0.999791 & $2.66 \mathrm{E}-26$ \\
\hline
\end{tabular}

\section{References}

1. Coles T, Hall CM (2008) International business and tourism: Global issues, contemporary interactions. Routledge.

2. United Nations (UN) (2012) Millennium Development Goals report.

3. United Nations (UN) (2015) Global Sustainable Development Report.

4. UNWTO (2018) Tourism and Sustainable Coals-Journey to 2030.

5. (2009) Eurobarometer.

6. IPCC (2007a) Climate Change 2007: The Physical Science Basis Contribution of Working Group I to the Fourth Assessment Report of the Intergovernmental Panel on Climate Change. In: Solomon SD, Qin M Manning, Z Chen, M Marquis, KB Averyt, et al. (Eds.). Cambridge University Press, Cambridge, United Kingdom and New York, NY, USA.

7. IPCC (2012) Managing the Risks of Extreme Events and Disasters to Advance Climate Change Adaptation. A Special Report of Working Groups I and II of the Intergovernmental Panel on Climate Change. In: Field CB, V Barros, TF Stocker, D Qin, DJ Dokken, et al. (Eds.), Cambridge and New York: Cambridge University Press, USA.

8. IPCC (2014).

9. UNWTO Tourism Highlights: 2017 Edition.

10. UNWTO (2019) Compendium of Tourism Statistics, Data 2013-2017.

11. Emanuel K (2005) Increasing destructiveness of tropical cyclones over the past 30 years. Nature 436(7051): 686-688.

12. Mimura N, Nurse L, McLean R, Agard J, Briguglio L, et al. (2007) Small islands. Climate Change 16: 687-716.

13. Burke L, Maidens J (2004) Reefs at Risk in the Caribbean (Washington, DC World Resources Institute, 2004), 60.

14. Waddell J, Clarke A (2008) The State of Coral Reef Ecosystems of the United States and Pacific Freely Associated States: 2008 (Silver Spring, MD: NOAA Tech. Memorandum NOS NCCOS 73, 2008), p. 569.

15. Trenberth KE (2008) The Impact of Climate Change and Variability on Heavy Precipitation, Floods, and Droughts. The Encyclopedia of Hydrological Sciences, Chichester, John Wiley \& Sons, Ltd, UK.

16. Yang MJ, Braun SA, Chen DS (2011) Water Budget of Typhoon Nari (2001). Monthly Weather Review 139(12): 3809-3828.

17. Kossin JP, Knapp KR, Vimont DJ, Murnane RJ, Harper BA (2007) A globally consistent reanalysis of hurricane variability and trends. Geophysical Research Letters 34(4): L04815.

18. Elsner JB, Kossin JP, Jagger TH (2008) The increasing intensity of the strongest tropical cyclones. Nature 455(7209): 92-95.

19. Hurricanesscience (2019).

20. Ranger N, Surminski S (2012) A preliminary assessment of the impact of climate change on non-life insurance demand in the BRICS economies. International Journal of Disaster Risk Reduction 3: 14-30.
21. Ward RET, Herweijer C, Patmore N, Muir-Wood R (2008) The role of Insurers in Promoting Adaptation to the Impacts of Climate Change. The Geneva Papers on Risk and Insurance-Issues and Practice 33(1): 133-139.

22. American International Group Inc (2006) 2006 Annual Report.

23. Lloyd's of London (2005) 2005 Annual Report.

24. Swiss Reinsurance Company (2005) 2005 Annual Report.

25. Berkshire Hathaway Inc (2006) 2006 Annual Report.

26. Taub S (2005) AIG, Berkshire Estimate Katrina Losses.

27. Sachdev A (2005) Katrina's cost gives Allstate biggest loss.

28. Denham R (2010) How State Farm fought through the second storm.

29. Hurricanes.

30. Vermieren J (2000) Risk transfer and finance experience in the Caribbean. Managing Disaster Risk in Emerging Economies, pp. 166174.

31. Kleindorfer PR, Kunreuther H (1999) The complementary roles of mitigation and insurance in managing catastrophic risks. Risk analysis 19(4): 727-738.

32. ECLAC (1982) Nicaragua: Las inundaciones de mayo de 1982 y sus repercusiones sobre el desarrollo economico y social del pais. Report No.E/CEPAL/MEX/1982/R.2/Rev.1. New York, Economic Commission for Latin American Countries, United Nations.

33. ECLAC (1985) Damage caused by the Mexican earthquake and its repercussions upon the country's economy. Santiago de Chile, Economic Commission for Latin America and the Caribbean.

34. ECLAC (1988) Damage caused by Hurricane Joan in Nicaragua: Its effects on economic development and living conditions, and requirements for rehabilitation and reconstruction. New York, Economic Commission for Latin American Countries, United Nations.

35. ECLAC (1999) Manual for estimating the socio-economic effects of natural disasters. New York City, United Nations Economic Commission for Latin America and the Caribbean, International Decade for Natural Disaster Reduction.

36. ECLAC (2002) Handbook for estimating socio-economic and environment effects of disasters. Mexico City, ECLAC.

37. ECLAC, IDB (2000) A matter of development: how to reduce vulnerability in the face of natural disasters. Seminar "Confronting Natural Disasters: A Matter of Development", New Orleans, 2526.3.2000.

38. Albala-Bertrand JM (1993) Political Economy of Large Natural Disasters with Special Reference to Developing Countries. Oxford, Clarendon Press.

39. Hochrainer S (2006) Macroeconomic risk management against natural disasters. Wiesbaden, German University Press (DUV). 
40. Hochrainer S (2009) Assessing the macroeconomic impacts of natural disasters: are there any? World Bank Policy Research Working Paper Series.

41. Crowards T (2000) Comparative vulnerability to natural disasters in the Caribbean. Charleston, South Carolina, Caribbean Development Bank.

42. Charvériat C (2000) Natural disasters in Latin America and the Caribbean: An overview of risk.

43. Caribbean Planning for Adaptation to Global Climate Change (1997).

44. Lemy MH (1998) Coastal and marine resources management in Latin America and the Caribbean. Inter-American Development Bank.

45. Donahue (1998) as cited by Joint United Nations Program on HIV/ AIDS (1999, p. 18).

46. Ritchie BW (2004) Chaos, crises and disasters: a strategic approach to crisis management in the tourism industry. Tourism Management 25(6): 669-683.

47. Ritchie BW (2008) Tourism disaster planning and management: From response and recovery to reduction and readiness. Current issues in Tourism 11(4): 315-348.

48. Cinar E. M, Johnson J, Palmer A (2013) Decision making: Fishing production and fishers in the Black Sea. Fisheries Research 147: 296303

49. Hilmi N, Safa A, Cinar M (2012) Decision Making Tools: How to Best Manage the Coral Reefs? Proceedings of the 12th International Coral Reef Symposium, Caims, Australia. 22D Economic Valuation and Market-Based Conservation.
50. Munich Re, Topics 2000: Natural Catastrophes-the Current Position, p 64.

51. Nutter F (1999) Global Climate Change: Why U.S. Insurers Care. Reinsurance Association of America. Kramer Academic Publishers.

52. Goovaerts MJ, De Vylder F (1984) A Stable Algorithm for Evaluation of Ultimate Ruin Probabilities. ASTIN Bulletin 14: 53-59.

53. Dufresne F, Gerber H (1989) Three Methods to Calculate the Probability of Ruin. ASTIN Bulletin 19(1): 71-90.

54. Anderson J, Brown R (2005) Risk and Insurance. Society of Actuaries, pp. 1-16.

55. Centre on the Epidemiology of Disasters (CRED). 2000. EM-DAT: The OFDA/CRED International Disaster Database 1900-1999. www.md.ucl. ac.be/cred. Louvain, Belgium: Université Catholique de Louvain.

56. IFID Centre on the Society of Actuaries.

57. NBC News (2005) AIG puts Katrina losses at \$1.1 billion.

58. Venter GG (1991) Premium implications of reinsurance without arbitrage. ASTIN Bulletin 21(2): 223-230.

59. Wang SS (2001) Equilibrium Pricing Transforms: New Results of Buhlmann's 1980 Economic Model. University of Waterloo, Institute of Insurance and Pension Research.

60. Yu L, Weller RA (2007) Objectively analyzed air-sea heat fluxes for the global ice-free oceans (1981-2005). Bulletin of the American Meteorological Society 88(4): 527-540.

Your next submission with Juniper Publishers will reach you the below assets

- Quality Editorial service

- Swift Peer Review

- Reprints availability

- E-prints Service

- Manuscript Podcast for convenient understanding

- Global attainment for your research

- Manuscript accessibility in different formats

( Pdf, E-pub, Full Text, Audio)

- Unceasing customer service

Track the below URL for one-step submission https://juniperpublishers.com/online-submission.php 